\title{
The Role of Endoscopic Retrograde Cholangiopancreatography in the Management of Biliary Complication Post-Laparoscopic Cholecystectomy
}

\author{
Mohammad Abdzaid Akool, Samer Makki Mohamed Al-Hakkak*, Alaa Abood Al-Wadees \\ Department of Surgery, Faculty of Medicine, Jabir Ibn Hayyan Medical University, Najaf City, Iraq
}

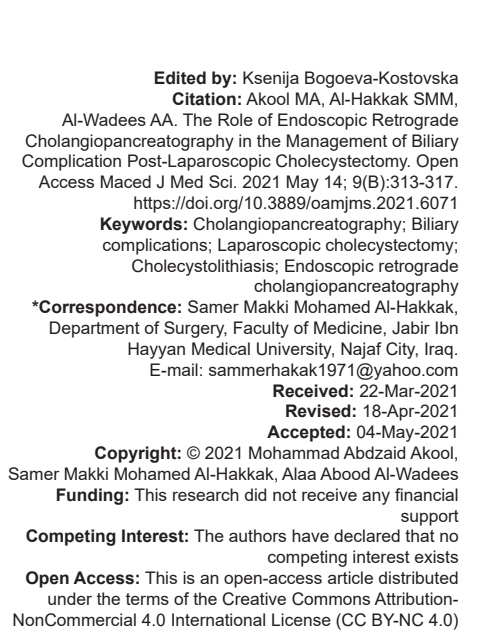

Abstract

BACKGROUND: Laparoscopic cholecystectomy considers a golden surgery for gallbladder removal nowadays, and it carries some complications like biliary injuries, which can manage successfully by endoscopic retrograde cholangiopancreatography.

AIM: To estimate the role of endoscopic management of bile duct injury (BDI) following laparoscopic cholecystectomy. PATIENT AND METHODS: A prospective study conducted at Al-Sader Medical City, Najaf City, Iraq, during the period between September 2018 and December 2020, included 44 patients complicated by the biliary injury resulting in a persistent biliary leak and/or jaundice after laparoscopic cholecystectomy and evaluated by endoscopic retrograde cholangiopancreatography (ERCP).

RESULTS: Findings revealed that $25 \%$ of cases had complete BDI, only one managed by plastic stent placement, the other 10 referred for open surgical constructions, $61 \%$ had partial injury associated with the biliary leak, al managed by sphincterotomy and plastic stent placement through ERCP, almost $7 \%$ had a partial clipping of bile duct all managed with sphincterotomy, balloon dilatation/stone extraction, and plastic stent placement, $5 \%$ had slipped clips of cystic duct stump, are managed with sphincterotomy and plastic stent placement. Moreover, only one patient, $2 \%$, had distal common bile duct stone with bile leak, managed by sphincterotomy and stone extraction.

CONCLUSIONS: Laparoscopic cholecystectomy, a gold standard therapeutic option for symptomatic cholecystolithiasis, is associated with an increased risk of biliary injury due to many factors. ERCP is a safe means of diagnosing the cause of bile leakage after laparoscopic cholecystectomy. It also offers definitive treatment in most cases by endoscopic sphincterotomy and plastic stent placement.

\section{Introduction}

Today, laparoscopic cholecystectomy is the treatment of choice for symptomatic gallstones with a minimally invasive procedure, minor pain, scarring, and early return to full activity [1], [2], [3]. The spectrum of complications in laparoscopic gallstone surgery (incidence of $0.85 \%$, major, i.e., complete transection or clipping $\approx 0.55 \%$ and minor, i.e., cystic stump leak, partial bile duct injury $[\mathrm{BDI}] \approx 0.3 \%$ ) has changed compared to open procedure such as BDI tends to be complex (as there is the involvement of new instruments such as stapling device and energized instruments), being more proximal and often associated with concomitant vascular injury [4], [5]. This along with injuries during access into peritoneal cavity such as bowel and major retroperitoneal vascular injury [6-8]. The bile duct complications can attribute to basic errors such as misinterpretations of the anatomy and technical errors or risk factors related to the surgeon, patient, or local pathology [9], [10], [11], [12]. Endoscopic retrograde cholangiopancreatography (ERCP) has evolved from a purely diagnostic to an almost exclusively therapeutic procedure. ERCP performs with a side-viewing duodenoscopy that allows identification of the major papilla. The bile duct cannulated under endoscopic and fluoroscopic guidance. A variety of catheters, guide wires, and stents is available to allow diagnostic and therapeutic interventions to perform [13], [14]. Many biliary indications for ERCP including bile duct stones, bile leaks [15], and benign biliary strictures [16]. The objective of our study was to demonstrate the effective role of ERCP in the management of post-laparoscopic cholecystectomy biliary complications.

\section{Patients and Methods}

A prospective study included 44 patients subjected to laparoscopic cholecystectomy in different hospitals (official and private) and complicated by biliary injury (leak and/or jaundice). They referred to the ERCP unit in Al-Sader Medical City from September 2018 to 
December 2020. Baseline investigations performed, supportive treatment administered, all the patients received prophylactic antibiotics, bowel relaxation achieved. ERCP evaluation performed with a sideviewing duodenoscopy that allows identification of the major papilla. The bile duct cannulated under endoscopic and fluoroscopic guidance. A variety of catheters, guide wires, and plastic stents are available to allow therapeutic interventions to introduce a water-soluble contrast (lohexol 350) under low pressure after bile duct cannulation to identify the biliary tree configuration under fluoroscopic guidance. After completing the procedure, the patient had kept under observation for at least $24 \mathrm{~h}$. Patients who had a significant injury and subjected to therapeutic interventions were kept for longer (maximum 2 weeks) until their biochemical and clinical conditions started to improve. Follow-up endoscopic cholangiogram was performed for all the 44 patients after 8 weeks to confirm the healing by contrast configuration of the biliary tree and stent removal. Data managed using the Statistical Package for the Social Sciences (SPSS) version 17. Ethical approval took from all patients to share their data.

\section{Results}

Patients were $30(68 \%)$ females and $14(32 \%)$ males, with a mean age of $47.9 \pm 15.6$ (range: $20-78$ ) years. Duration of symptomatic gallstone disease ranged from 10 days to 18 months (mean $5.8 \pm 4.8$ months), and the majority of the patients had their symptomatic gallstone disease for 2-6 months. In general, bile leak was more than $200 \mathrm{ml} /$ day and jaundice, out of the 44 patients, 9\% presented with jaundice only, 14\% with persistent leak and jaundice, while $77 \%$ with persistent leak only as shown in Table 1 and Figure 1. The mean time between the surgery and ERCP intervention was 22.7 days. Out of the 44 patients, 27 had partial transection injury, 11 complete injuries, three partial clipping of bile duct, two slipped clips of the cystic duct

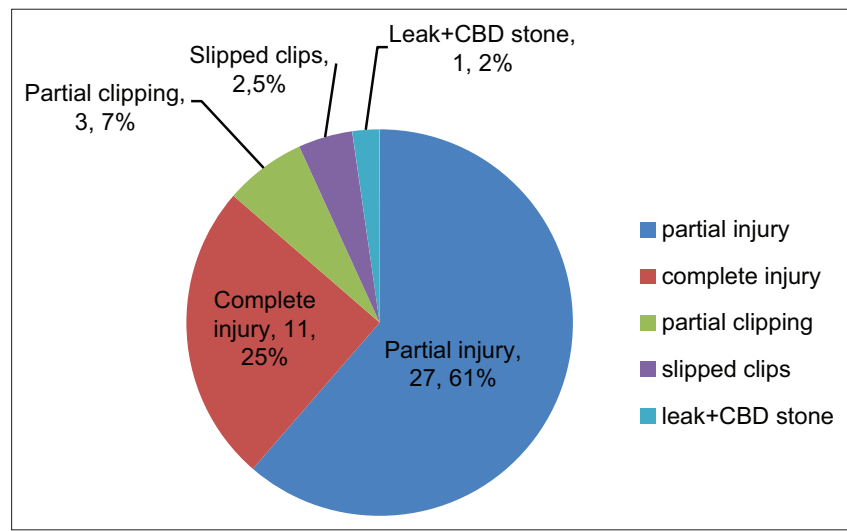

Figure 1: The type of the biliary complications post-laparoscopic cholecystectomy
Table 1: The duration of symptoms pre-operative and the type of complications

\begin{tabular}{lllllll}
\hline $\begin{array}{l}\text { Duration } \\
\text { interval }\end{array}$ & \begin{tabular}{l} 
Laparoscopic complications \\
\cline { 2 - 5 }
\end{tabular} & $\begin{array}{l}\text { CBD stone+ } \\
\text { mild leak }\end{array}$ & $\begin{array}{l}\text { Complete injury } \\
\text { (cut and clipping) }\end{array}$ & $\begin{array}{l}\text { Partial clipping } \\
\text { of CBD }\end{array}$ & $\begin{array}{l}\text { Partial } \\
\text { injury }\end{array}$ & $\begin{array}{l}\text { Slipped } \\
\text { clips }\end{array}$ \\
\hline$<=1$ month & 0 & 1 & 0 & 3 & 0 & $4(9)$ \\
$2-6$ months & 1 & 9 & 2 & 12 & 1 & $25(57)$ \\
$7-11$ months & 0 & 0 & 0 & 6 & 0 & $6(14)$ \\
$12-18$ months & 0 & 1 & 1 & 6 & 1 & $9(20)$ \\
Total & 1 & 11 & 3 & 27 & 2 & $44(100)$ \\
\hline CBD: Common bile duct & & & & & &
\end{tabular}

stump, and only one patient had distal common bile duct (CBD) stone with mild bile leak, as shown in Figure 2. The 27 patients who had partial injury managed by sphincterotomy and stent placement of size (8.5 or 10 $\mathrm{F}), 7 / 27$, required more than 1 stent replacement or placement every 12-week distal CBD stricture up to 1 year. In contrast, the other $20 / 27$ required one stent that

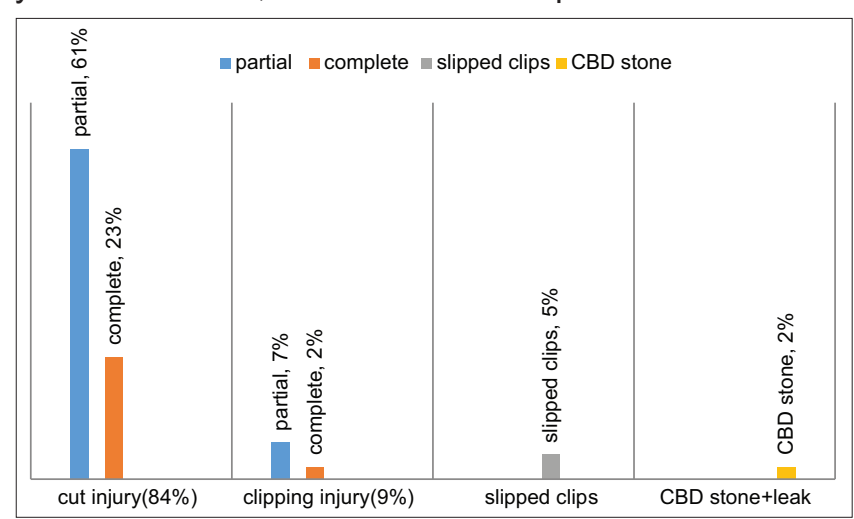

Figure 2: The type of biliary injuries

had been removed 2 months after confirmation that there was no more leak with good visualization of the proximal biliary tree by endoscopic retrograde cholangiogram as shown in Table 2 and Figure 3. The two patients who had slipped clips managed by sphincterotomy and stent placement removed 2 months later. The one patient with mild bile leak and on ERCP founded to have distal CBD stone only, so he was managed by sphincterotomy and balloon stone

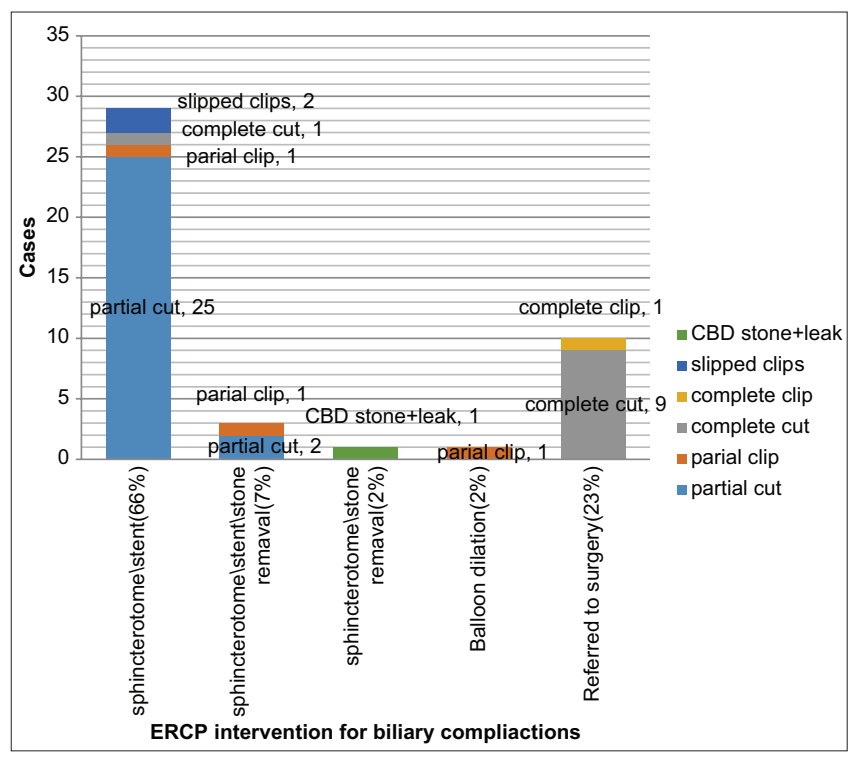

Figure 3: Endoscopic retrograde cholangiopancreatography intervention for biliary complication 
Table 2: Laparoscopic complications and ERCP management

\begin{tabular}{|c|c|c|c|c|c|c|}
\hline \multirow{2}{*}{$\begin{array}{l}\text { Laparoscopic } \\
\text { complication }\end{array}$} & \multicolumn{5}{|l|}{ ERCP interventions } & \multirow[t]{2}{*}{ Total } \\
\hline & Sphincterotomy/stent & Sphincterotomy/stent/stone removal & Sphincterotomy/stone removal & Balloon dilation & Referred to surgery & \\
\hline Partial CBD cut & 25 & 2 & 0 & 0 & 0 & 27 \\
\hline Partial CBD clipping & 1 & 1 & 0 & 1 & 0 & 3 \\
\hline Complete CBD cut & 1 & 0 & 0 & 0 & 9 & 10 \\
\hline Complete CBD clipping & 0 & 0 & 0 & 0 & 1 & 1 \\
\hline Slipped clips & 2 & 0 & 0 & 0 & 0 & 2 \\
\hline CBD stone+leak & 0 & 0 & 1 & 0 & 0 & 1 \\
\hline Total $(\%)$ & $29(66)$ & $3(7)$ & $1(2)$ & $1(2)$ & $10(23)$ & $44(100)$ \\
\hline
\end{tabular}

extraction. 3/44 patients who had a partial clipping of bile ducts managed by sphincterotomy, balloon dilation of stricture, and plastic stent placement after introducing a guidewire to bypass the stricture, only one patient had distal CBD stone and extracted by the balloon, the patient who had distal CBD stricture required multiple sessions of balloon dilation and stent replacement every 12 weeks for 1 year as shown in Table 3 and Figure 3. Eleven out of 44 patients (25\%) diagnosed to have complete injury $10 / 44(22.73 \%)$ had complete transection injury confirmed by non-visualization of the proximal part of bile duct with leakage of contrast material into the surrounding spaces so that they were referred for surgical intervention except one case which successfully managed to bypass the guidewire to the divided proximal segment then placing $8.5 \mathrm{~F}^{*} 12 \mathrm{~cm}$ stent connecting both distal and proximal

Table 3: ERCP intervention sessions and follow-up

\begin{tabular}{|c|c|c|c|c|}
\hline \multirow{2}{*}{$\begin{array}{l}\text { Laparoscopic } \\
\text { complication }\end{array}$} & \multicolumn{2}{|c|}{ Only 1 ERCP session } & \multicolumn{2}{|c|}{$\geq 2$ ERCP sessions } \\
\hline & Diagnosis & $\begin{array}{l}\text { Diagnosis and } \\
\text { treatment }\end{array}$ & $\begin{array}{l}\text { Stent removal } \\
\text { after } 2 \text { months }\end{array}$ & $\begin{array}{l}\geq 2 \\
\text { stents }\end{array}$ \\
\hline Partial cut & 0 & 0 & 20 & 7 \\
\hline Partial clipping & 0 & 1 & 1 & 1 \\
\hline Complete cut & 9 & 0 & 1 & 0 \\
\hline Complete clipping & 1 & 0 & 0 & 0 \\
\hline Slipped clips & 0 & 0 & 2 & 0 \\
\hline CBD stone + leak & 0 & 1 & 0 & 0 \\
\hline Total $(\%)$ & $10(22)$ & $2(5)$ & $24(55)$ & $8(18)$ \\
\hline
\end{tabular}

segments of the bile duct. Two months later, endoscopic retrograde cholangiogram revealed complete healing, no further contrast leak, and visualization of the biliary tree permitting stent removal. Further, follow-up had been planned because stricture may develop later on. One of $44(2.27 \%)$ had complete clipping injury, that is, visualization of the distal part of bile duct with cut line proximally and contrasted backflow to the duodenum, and referred for surgical reconstruction as shown in Table 3 and Figure 4.

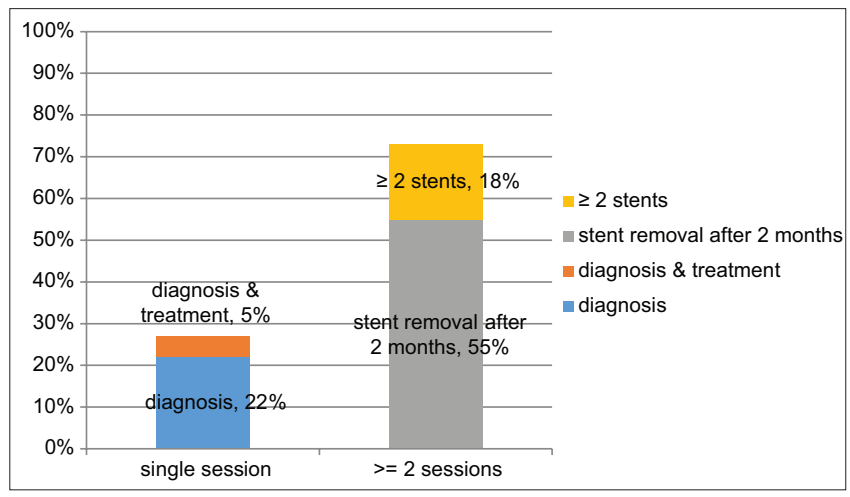

Figure 4: Endoscopic retrograde cholangiopancreatography intervention sessions and follow-up

\section{Discussion}

In our results, we found that biliary complications were more frequent in female patients. Our study agreed with the previous studies and agreed with regard to age distribution [17], [18], [19], [20], but disagreed with them regarding the distribution of complications by age groups. Symptomatic gallstone disease in $57 \%$ of patients reported for 2-6 months, and this agreed with findings of Harboe and Bardram, Al-Kubati, and Lo et al. [18], [21], [22], the latter observed that the presence of dense fibrous adhesions in the delayed group made laparoscopic dissection difficult and unsafe [22]. The least proportion of patients was from Baghdad teaching hospital; this may reflect the surgeons' expert, which agrees with Boddy et al. [23]. They found that as a result of consultant appointments and a greater degree of specialization within the general surgical department, a larger proportion of cholecystectomies had a shorter theatre time and was more likely to be completed with a lower rate of BDI. The results disagree with Al-Kubati [21] that found the most laparoscopic complications occurred by a senior surgeon rather than a junior surgeon. In Iraq, tube drain has generally been used in cholecystectomy surgeries (open or laparoscopic), decreasing the chances of biloma and bilious peritonitis, allowing bile leak discovered early. Therefore, the most significant symptom was a persistent bile leak of more than $200 \mathrm{ml} /$ day. The ERCP intervention revealed different types of injuries; however, in the previous studies, the sequences of these injuries were different than ours, and this attributed to the differences in the facilities of different countries and hospitals [21], [24], [25], [26] Management by ERCP was successful in minor biliary complications, while in the complete injury, ERCP was restricted to diagnostic advantage. Nonetheless, the majority of patients in our study had been diagnosed and treated successfully by ERCP. The study agreed with Christoforidis et al. [26], Abdel-Raouf et al. [25], Bose et al. [27], and Al-Kubati [21], also agree with Karvonen et al. [28] regarding the cystic stump leak and complete injury but disagree with him regarding partial BDI as they treat this injury surgically.

\section{Conclusions}

Laparoscopic cholecystectomy was associated with an increased risk of biliary injury. ERCP is a safe 
procedure for diagnosing the cause of biliary leakage following laparoscopic cholecystectomy. It also offers a definitive treatment in most cases (partial injury and cystic leak) either by endoscopic sphincterotomy alone or in conjunction with biliary plastic stenting. In contrast, the major biliary complications (complete transection or clipping), the ERCP intervention is limited to a diagnostic role, and these cases need to be constructed by open surgery.

\section{Authorship}

1. Mohammad Abdzaid Akool: Study design, conception, data analysis, and interpretation

2. Samer Makki Mohamed Al-Hakkak: Corresponding author, data collection and analysis, drafting the article, revising it critically for important intellectual content, and final approval of the version to be submitted

3. Alaa Abood Al-Wadees: Data acquisition, analysis, and interpretation.

\section{References}

1. Pham TH, Hunter JG. Gallbladder and the extrahepatic biliary system. In: Schwartz Principles of Surgery. $9^{\text {th }}$ ed., Vol. 32. New York: McGraw-Hill; 2010.

2. Fletcher DR. Gallstones. Modern management. Aust Fam Physician 2001;30:441.

3. Giger U, Ouaissi M, Schmitz SF, Krahenbuhl S, Krahenbuhl L. Bile duct injury and use of cholangiography during laparoscopic cholecystectomy. Br J Surg. 2011;98(3):391-6. https://doi. org/10.1002/bjs. 7335

PMid:21254014

4. Shamiyeh A, Wayand W. Laparoscopic cholecystectomy: Early and late complications and their treatment. Langenbecks Arch Surg. 2004;389(3):164-71. https://doi.org/10.1007/ s00423-004-0470-2

PMid:15133671

5. Nuzzo G, Giuliante F, Giovannini I, Ardito F, D'Acapito F, Vellone $\mathrm{M}$, et al. Bile duct injury during laparoscopic cholecystectomy: Results of an Italian National Survey on 56591 cholecystectomies. Arch Surg. 2005;140(10):986-92. https://doi.org/10.1001/archsurg.140.10.986 PMid:16230550

6. Zha $Y$, Chen XR, Luo D, Jin Y. The prevention of major bile duct injures in laparoscopic cholecystectomy: The experience with 13,000 patients in a single centre. Surg Laparosc Endosc Percutan Tech. 2010;20(6):378-83. https://doi.org/10.1097/ sle.0b013e3182008efb

PMid:21150413

7. Schmidt SC, Langrehr JM, Hintze RE, Neuhaus P. Long-term results and risk factors influencing the outcome of major bile duct injuries following cholecystectomy. Br J Surg. 2005;92(1):76-82. https://doi.org/10.1002/bjs.4775

PMid:15521078
8. Kapoor VK. Management of bile duct injuries: A practical approach. Am Surgeon. 2009;75(12):1157-60.

PMid:19999903

9. Gossage JA, Forshaw MJ. Prevalence and outcome of litigation claims in England after laparoscopic cholecystectomy. Int J Clin Pract. 2010;64(13):1832-5. https://doi. org/10.1111/j.1742-1241.2009.02200.x

PMid:21070534

10. Gigot JF, Etienne J, Aerts R, Wibin E, Dallemagne B, Deweer F, et al. The dramatic reality of biliary tract injury during laparoscopic cholecystectomy: An anonymous multicenter Belgian survey of 65 patients. Surg Endosc. 1997;11(12):1171-8. https://doi. org/10.1007/s004649900563

PMid:9373288

11. Strasberg SM, Helton WS. An analytical review of vasculobiliary injury in laparoscopic and open cholecystectomy. HPB (Oxford). 2011;13(1):1-14. https://doi. org/10.1111/j.1477-2574.2010.00225.x

PMid:21159098

12. Cuschieri SA, Steele RJ, Moossa AR. Biliary tract disease. In: Cuschiery's Essential Surgical Practice. $4^{\text {th }}$ ed., Vol. 28. London: Arnold; 2002.

13. Feldman $\mathrm{M}$, Friedman $\mathrm{L}$, Brandt L. Biliary tract disease: Endoscopic and radiological treatment. In: Sleisenger and Fordtran's Gastrointestinal and Liver Disease. $9^{\text {th }}$ ed., Ch. 70. Amsterdam, Netherlands: Elsevier; 2010. https://doi. org/10.1016/b978-1-4160-6189-2.00133-5

14. Carr-Locke DL. Therapeutic role of ERCP in the management of suspected common bile duct stones. Gastrointest Endosc. 2002;56(Suppl 6):S170-4. https://doi.org/10.1067/ mge.2002.129024

PMid: 12447262

15. Baron TH. Endoscopy for bile duct stones. Minerva Gastroenterol Dietol. 2005;51(4):289-301.

PMid:16282958

16. Katsinelos P, Kountouras J, Paroutoglou G, Chatzimavroudis G Germanidis G, Zavos C, et al. A comparative study of 10-Frvs 7-Fr straight plastic stents in the treatment of postcholecystectomy bile leak. Surg Endosc. 2008;22:101-6. https://doi.org/10.1007/ s00464-007-9381-y

PMid: 17516115

17. Machado NO. Biliary complications post laparoscopic cholecystectomy: mechanism, preventive measures, and approach to management. Diagn Ther Endosc. 2011;2011:967017. https://doi.org/10.1155/2011/967017 PMid:21822368

18. Harboe KM, Bardram L. The quality of cholecystectomy in Denmark: Outcome and risk factors for 20,307 patients from the national database. Surg Endosc. 2011;25(5):1630-41. https:// doi.org/10.1007/s00464-010-1453-8

PMid:21136118

19. Harrison VL, Dolan JP, Pham TH, Diggs BS, Greenstein AJ, Sheppard BC, et al. Bile duct injury after laparoscopic cholecystectomy in hospitals with and without surgical residency programs. Surg Endosc. 2011;25(6):1969-74. https:// doi.org/10.1007/s00464-010-1495-y

PMid:21136094

20. Christos P, Mavromatis TN, Kourlaba GC, Kapiris SA, Bairamides EG, Spyrou AM, et al. Is inflammation a significant predictor of bile duct injury during laparoscopic cholecystectomy? Surg Endosc. 2008;22(9):1959-64. https://doi.org/10.1007/ s00464-008-9943-7

PMid: 18443865

21. Al-Kubati WR. A clinical study of bile duct injury following laparoscopic cholecystectomy. Saudia J Gastroenterol. 
2010;16(2):100-4. https://doi.org/10.4103/1319-3767.61236 PMid:20339179

22. Lo CM, Liu CL, Fan ST, Lai EC, Wong J. Prospective randomized study of early versus delayed laparoscopic cholecystectomy for acute cholecystitis. Ann Surg. 1998;227(4):461-7. https://doi. org/10.1097/00000658-199804000-00001 PMid:9563529

23. Boddy AP, Bennett JM, Ranka S, Rhodes M. Who should perform laparoscopic cholecystectomy? A 10-year audit. Surg Endosc. 2007;21(9):1492-7. https://doi.org/10.1007/s00464-007-9291-z PMid: 17484005

24. Prakash K, Jacob G, Lekha V, Venugopal A, Venugopal B, Ramesh H. Laparoscopic cholecystectomy in acute cholecystitis. Surg Endosc. 2002;16(1):180-3. https://doi.org/10.1007/ s004640080193

PMid:11961635

25. Abdel-Raouf A, Hamdy E, El-Hanafy E, El-Ebidy G. Endoscopic managementofpostoperativebileductinjury. SaudiaJGastroenterol.
2010;16(2):19-24. https://doi.org/10.4103/1319-3767.58763 PMid:20065569

26. Christoforidis E, Goulimaris I, Tsalis K, Kanellos I, Demetriades H, Betsis D. The endoscopic management of persistent bile leakage after laparoscopic cholecystectomy. Surg Endosc. 2002;16(5):843-6. https://doi.org/10.1007/s00464-001-9091-9 PMid:11997834

27. Bose SM, Mazumdar A, Singh V. The role of endoscopic procedures in the management of post-cholecystectomy and post-traumatic biliary leak. Surg Today. 2001;31(1):45-50. https://doi.org/10.1007/s005950170219

PMid:11213042

28. Karvonen J, Gullichsen R, Laine S, Salminen P, Groönroo JM. Bile duct injuries during laparoscopic cholecystectomy: Primary and long-term results from a single institution. Surg Endosc. 2007;21(7):1069-73. https://doi.org/10.1007/ s00464-007-9316-7

PMid:17514397 